\title{
A Brief Insight into Microbial Corrosion and its Mitigation with Eco-friendly Inhibitors
}

\author{
M. Lavanya ${ }^{1}$
}

Received: 22 February 2021 / Revised: 10 June 2021 / Accepted: 4 July 2021 / Published online: 8 July 2021

(C) The Author(s) 2021

\begin{abstract}
Corrosion results from the electrochemical reactions between the metal and its existing environment. Corrosion results in severe and expensive damage to a wide spectrum of industries. When microbes are involved in corrosion it is seldom possible to economically evaluate its impact. Microbially influenced corrosion is recognized to cause catastrophic failures contributing to approximately $20 \%$ of the annual losses. In many engineering applications, microbially influenced corrosion control is of prime importance. Expensive, toxicity and sometimes, even ineffectiveness of the current chemical strategies to mitigate microbially influenced corrosion have shifted the interest towards eco-friendly inhibitors. The present review discusses microbial induced corrosion in various metals and its inhibition through eco-friendly inhibitors. In addition, the study also reviews the morphological and electrochemical impedance results.
\end{abstract}

Keywords Microbially influenced corrosion $\cdot$ Eco-friendly inhibitors $\cdot$ Metal $\cdot$ Electrochemical impedance

\section{Introduction}

Degradation of metals by means of interaction with their associated environment is known as corrosion. Sometimes this term corrosion is also applied to deterioration of concrete, plastic and wood but often is considered with respect to metals [1]. Higher operating and maintenance costs, catastrophic failures are all consequences of corrosion [2]. World wide corrosion losses in 2015 was $~ 2.5$ trillion dollars [3]. Out of the many techniques employed to eliminate or reduce corrosion the most practical method is the application of inhibitors [4]. Biocorrosion is one among the eight different types of corrosion. In many industries such as power generation, waste water treatment plant, oil and gas production, MIC (Microbiologically Influenced Corrosion) has been identified as most dangerous [5].

MIC contributes to approximately $20 \%$ of the annual losses [6-8]. MIC is not a new form of corrosion, but to date, it is a more serious and dangerous problem of the industry. In 1891, the scientist Garrett studied microbial corrosion, it

\footnotetext{
M. Lavanya

lavanya.m@manipal.edu

1 Department of Chemical Engineering, Manipal Institute of Technology, Manipal Academy of Higher Education, Manipal, Karnataka, India
}

is the first report about microbes for corrosion [9]. MIC has significant ecologic and economic impact [10]. MIC was known to be a key factor for numerous pipeline failures. One such incident of pipeline rupture took place in New Mexico in the year 2000. MIC was also a main suspect in the pipeline leak in Alaska on March 2, 2006 which lead to a spike in oil prices world wide [11].

Biocorrosion may be prevented by reducing biofilm formation on the surface of the metal. Biocides and few dispersive agents are applied to the metal surface to reduce the formation of biofilm as a part of chemical treatment. Nevertheless these treatments have lost their applications due to the environmental concerns. Therefore development of eco-friendly inhibitors is drawing attention in the recent years [12].

This research article focused on the behavior of ecofriendly corrosion inhibitors on metals for microbial corrosion in various media.

\section{Microbial Corrosion Mechanism}

MIC is the consequence of the combination of "three $\mathrm{M}^{\prime}$ 's" (Fig. 1): microorganisms, media (chemical composition and physical parameters, e.g., temperature and flow), and metals [9]. 
Fig. 1 Schematic representation of the effects of media, metal and microorganisms on MIC

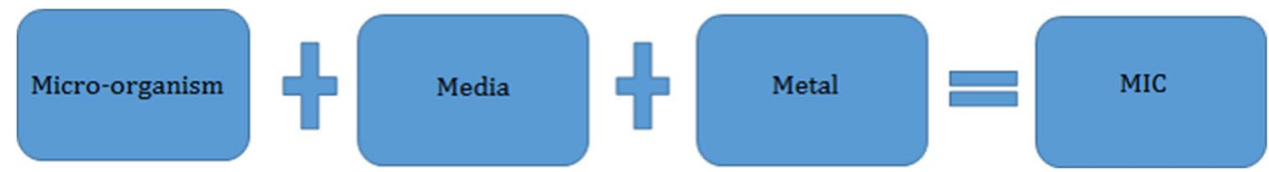

Table 1 Microbes involved in corrosion and its classification [18]

\begin{tabular}{ll}
\hline Bacteria & Sulphur oxidizing bacteria \\
\hline & APB (inorganic Sulphur acid by \\
& Acidothiobacillus, organic by \\
& Bacillus sp. \\
& Sulphur reducing bacteria \\
& Slime producing bacteria \\
& Iron reducing bacteria \\
Fungi & Aspergillus Niger \\
& Penicillium cyclospium \\
Algae & Blue green algae \\
\hline
\end{tabular}

A combination of microorganisms, media and metal together lead to microbial corrosion which is shown diagrammatically in Fig. 1. Biocorrosion frequently occurs due to pitting corrosion subsequently allowing the microbes to accumulate in specific places repeatedly [13]. It is an electrochemical phenomena where microorganisms accelerate material degradation by their metabolic action on the material [14].

Bio-corrosion is connected with microbes or the metabolites resulting from their activities which include exopolymers, enzymes, acids and volatile compounds. The cathodic and the anodic reactions are affected by these metabolites leading to a variation in the metal interface electrochemistry. The main bacteria involved in the corrosion of mild steel, cast iron and stainless steel are sulfur oxidizing bacteria, SRB (Sulfate-Reducing Bacteria), manganese oxidizing bacteria, iron-oxidizing/reducing bacteria, etc. These microbes stimulate corrosion in several ways. $[15,16]$. These microbes coexist in naturally arising biofilms, frequently developing synergistic consortia. During microbial corrosion, the microbes initiate, facilitate and aggravate corrosion through co-operative metabolism and then develop a biofilm on the metal surface. Material and microbe interactions cause the bacteria to adhere and form a biofilm. Biofilm consists of $95 \%$ water with Extracellular Polymeric Substance (EPS) and inorganic matter/cell suspension. The environmental factors strongly affect the development of microbial community within the biofilm. Biofilm is also responsible in transforming the properties at the metal/solution interface [17]. The microbes involved in corrosion process are listed in Table 1.

\section{Microbial Corrosion in Metals}

Microbes can directly or indirectly disturb the integrity of many metals used in industrial applications. Most of them including copper, iron, nickel, aluminum and their alloys, are more or less vulnerable to damage. Only titanium and its alloys appear to be usually resistant [19].

\subsection{Aluminum Magnesium Alloy}

The 2024-T31 aluminum-magnesium alloy was investigated for its susceptibility to microbial corrosion in the presence of SRB. The sample was immersed in various test solutions and maintained at constant temperature of $30^{\circ} \mathrm{C}$ in an incubator. As time elapsed microbial colonies and deposition of corrosion products were observed on the substrate. Biofilm and passivation film both were found to jointly control corrosion in 2024-T31 aluminum-magnesium alloy. SRB caused excessive corrosion in the alloy along with pitting on the metal surface. In the very beginning an uneven biofilm was observed on the metal surface which weakened in the mid stage along with the growth of a protective passive film therefore reducing the corrosion rate. Later localized corrosion cells were formed accelerating corrosion [20].

\subsection{Carbon Steel, Copper Aluminum}

The growth cycle of SRB, Desulfovibriocaledoniensis, and the influence of SRB on the corrosion activities of Q235 and the environmental parameters during a growth cycle in the presence and absence of oxygen were studied. Culture solutions with dissolve oxygen encouraged sluggish growth and rapid decay of SRB. Conductivity, $\mathrm{pH}$ and sulphide anion concentration were affected by the growth process of SRB both under aerobic and anaerobic conditions. During the stationary growth phase OCP (Open Circuit Potential) shifted towards positive end. Through the exponential growth phase the Rct (charge transfer resistance) increased rapidly while it decreased after the stationary phase [21].

Corrosion behavior of carbon steel, pure aluminum and copper were studied in sea water. Epifluorescence microscopy and electrochemical techniques were applied for the investigation. Ecorr moved to the negative direction with time for carbon steel and aluminum. Corrosion causes the Ecorr to move towards the negative end. These 
metals easily corrode in sea water. On the corroding metal substrates biofilms does not form easily. Bacteria hardly adhere to the copper surface and therefore Ecorr seldom changed [22].

\subsection{Aluminum alloy}

Aluminum alloys find diverse applications owing to their excellent chemical and physical properties ranging from aircraft to construction [23-25]. Aluminum and its alloys offer corrosion resistance through a thin passive layer of aluminum oxide known as Alumina naturally formed on its surface [26].

Aluminum alloy (7065-T6) was investigated for its corrosion behavior in saline environment involving Aspergillus niger (A. niger). Methods and techniques used for the study included HPLC, GC, surface analysis and electrochemical measurements. The localized corrosion increased 2.4 times in the presence of A. Niger as compared to its absence. The increased corrosion rate was attributed to the enhanced cathode and anode reactions due to the presence of biofilm generated by A. Niger. Additionally A. Niger secreted organic acid was found to enhance corrosion. After the early adaptation period $A$. Niger adhered to the aluminum surface easily. $\mathrm{Al}(\mathrm{OH})_{3}$ and $\mathrm{AlO}(\mathrm{OH})$ were confirmed to be present as corrosion products through XRD analysis. In the presence of A.Niger corrosion accelerated which was confirmed through weight loss, surface analysis and electrochemical measurements [27].

Microbes present in the corrosion products of dieseltransporting pipelines, their corrosion effects on 2024 aluminum alloy was the topic of research. Microbes under study were Serratia marcescens ( $S$. marcescens) ACE2, a Gram-negative bacteria and Bacillus cereus ACE4, a Grampositive bacteria. Aeronautical fuel storage tanks often suffer microbial growth and contamination which result in corrosion further leading to higher operating and maintenance costs. The bacteria instigated pitting in the fuel tank. Bacteria develops biofilm when exposed to the salty environment. These biofilms are responsible for pitting corrosion. As compared to $S$. marcescens ACE2 corrosion damage caused by B. cereus ACE4 is more intense [28].

This report aims at evaluating the risk of MIC on 6061 Aluminum alloy and pure aluminum in spent nuclear fuel. Out of the identified microbes Bacillus cereus (B. cereus) RE 10 was the most predominant. This bacteria was selected for investigating its corrosion intensity of 6061 Aluminum alloy and pure aluminum. On the surface of 6061 Aluminum alloy deeper pits were observed after exposing it to B. cereus RE 10 for 20 days but no such observations were found on pure aluminum. A definite correlation was noticed between, corrosion deposits, biofilm patches and pitting [29].

\subsection{Carbon Steel}

Carbon steel (CS) is a material with properties such as good electrical and thermal conductivity and excellent mechanical strength. The cost of carbon steel is cheaper as compared to few other metals. However, one of the disadvantages of using this metal is that it rusts easily resulting in environmental and economic losses [30]. CS and its alloys are used all over the world in boilers, pipelines, bridges and so on. With relatively good corrosion resistance CS is also applied in marine environments [31]. A laboratory scale test set up was employed to study the effect of SRB on carbon steel corrosion. The test medium was North Sea water. The test medium was inoculated with a bacterial species namely Desulfovibrioalaskensis or Desulfovibriodesulfuricans. Also antimicrobial treatment was given to the flow cell. Higher electrochemical activity and hence lower corrosion resistance was exhibited by the steel coupons in the presence of the bacterial species. Pit formation increased with exposure time. However, bacterial action was provisionally blocked due to the antibacterial treatment. As a consequence of long term exposure biofilm and corrosion products were developed on the carbon steel specimen [32]. The authors report the MIC of API 5L X80 by SRB. The corrosion behavior of carbon steel was analyzed by electrochemical techniques along with field emission scanning electron microscopy (FESEM). The interactions between carbon steel, biofilm and the test solution was analyzed with the equivalent circuits obtained from EIS study. The biofilm formed on the metal substrate results in excessive localized corrosion. In addition, iron sulfide layer formed also contributes to corrosion. The iron sulphide layer formed is porous in nature. Corrosion product formed included various sulphide and oxide components as revealed by the EDS study [33].

\subsection{Zinc}

Zinc is widely used in construction, automobiles and shipping industries. Zinc offers a high resistance to corrosion by forming a passive layer of $\mathrm{ZnO}$ and $\mathrm{Zn}(\mathrm{OH})_{2}$ when exposed to the atmosphere [34]. It is ranked fourth among the metals that are produced and consumed worldwide [35]. In the Urban, rural and marine sites of Luthania, Aspergillus niger was isolated. Aluminum and Zinc were exposed to A. Niger for 2 years under humid conditions. A double layer corrosion product formed on the surface of zinc was detected from EIS analysis. The inner layer was thinner due to the microorganism activity but had an enhanced passivation capacity as compared to the outer layer. MIC affected the pores, microcracks present on the aluminum surface as confirmed from the decreased layer thickness and increased corrosion resistance. The study postulated that microbes assist 
in preventing corrosion and therefore may be considered as corrosion inhibitors in place of toxic chemicals [36].

Few microbes are known to cause severe corrosion in some of the metals. In the present study the influence of Desulfovibriovulgarison zinc and galvanized steel was investigated. Weight loss suffered by galvanized steel and zinc was 101 times greater than carbon steel. While comparing galvanized steel and zinc potentiodynamic studies indicated that zinc was more prone to SRB induced corrosion [34].

\subsection{Magnesium}

Magnesium finds its application in the area of military and aerospace [37]. It has been further extended to storage, electronics and also orthopedic implants. It has been considered to replace the heavy metal alloys in the near future. Magnesium and its alloys have outstanding properties, such as machinability, lightweight, shock absorption and impact resistance [38]. The corrosion behavior of magnesium alloy in the presence of SRB was reported in this study. X-Ray spectroscopy and SEM analysis of the corrosion film were carried out for knowing its composition. Additionally the morphology of the corrosion product and the mechanical properties of the alloy was also investigated. The results showed that SRB played a key role in the Magnesium alloy corrosion by enhancing pitting. Therefore SRB affect the residual strength of the alloy through enhanced pitting [39]. A specially designed method was employed to study MIC in magnesium alloy. It is known as solid culture medium method. Electrochemical method was used to study the corrosion behavior long with the surface analysis with Scanning electron microscopy (SEM). Presence of SRB resulted in excessive pitting of the alloy. The results indicated the characteristic feature of MIC as pitting. The key component responsible for pitting due to SRB involved hydrogenase enzyme. Cathodic reaction was accelerated due to SRB as indicated by the electrochemical study [40].

\subsection{Steel}

Steel is extensively used in engineering applications due to its ability to form passive layer on its surface and hence resist corrosion [41]. Stainless steels is generally used in processing equipment, heat exchangers, beverage industries, food factories and biomedical industries [42]. This metal has good resistance to various environments and corrosive solutions. The resistance to corrosion is confirmed by the presence of a passive film. The passive layer on stainless steel is naturally formed in water and air with a thickness of $10-100 \AA$. This layer consists of both chromium and iron oxide [43]. A variety of stainless steels with different microstructures were investigated for its influence on microbial corrosion. The effect of microstructure was studied in the presence of two species of SRB. The medium for study included Electrolyte A and Electrolyte B with different constituents. Biofilms were analyzed with the help of SEM. The metabolites of SRB caused a premature rupture of the passive films leading to formation of pits. A correlation between the pit morphology, its composition and medium composition was established [44].

This paper explores a serious microbiologically influenced failure in the elbows of a buried amine pipeline in a petrochemical plant. Out of the many different corrosion mechanisms MIC is one which the pipelines may experience. A systematic investigation has been carried out by the researchers which includes exhaustive corrosion product analysis, microstructural analysis and monitoring the presence of microorganisms. The failure of the pipeline was ascribed to the presence of SRB which is mainly responsible to MIC as indicated by other researchers. EDS spectra confirmed the existence of Sulphur indicating the role of SRB in inducing corrosion. SRB shows very good adaptability to extreme environment conditions. The damaging metabolic activities of SRB is concerned with its capacity to utilize organic compounds, aromatic and aliphatic hydrocarbons and also cause sulfate to sulfide reduction [45].

\subsection{Titanium}

Titanium is a metal which is highly resistant to corrosion. The stable oxide film formed on the surface of Titanium offers better corrosion resistance. Titanium alloys are applied in various fields ranging from automative to biomedical industries. It offers features like excellent mechanical properties, low density and light weight making it more attractive for the marine environment [46].

The corrosion performance of a titanium alloy was studied in a solution containing SRB. Initially SRB adhered to the surface of the alloy in small amounts progressively forming colonies and increased as time elapsed as indicated by the bacterial adhesion experimental study. The amount of Sulphur increased with the elapsed immersion time. Suplhur in small amount was perceived to have to have a protective effect. Nevertheless higher amount of Sulphur showed a detrimental effect on the oxide film. Pitting corrosion was observed on the alloy surface. Electrochemical studies indicated a better resistance in the initial time period of immersion and later showed a increased corrosion rate. This observation is attributed to the increased Sulphur content in the medium as greater immersion period [47]. Biocorrosion is a threat to many metals. The phenomena was studied in the presence of a microbe Pseudomonas aeruginosa. Pure titanium was the metal under study. Electrochemical test were conducted on the metal in the medium containing the marine bacterium. The metal was observed to be corrosion resistant up to 14 days of immersion whereas the resistance 
decreased after that time period due to the biofilm developed on the surface. Severe pitting corrosion was observed with a pit depth of $1.2 \mathrm{~m}$. The biofilm causes the passive film to be unstable [46].

Corrosion of titanium is the major concern when it is used for dental treatment. This study aimed to investigate the mechanism of the microbiologically induced corrosive properties of titanium. An experimental well was made of polymethyl methacrylate with pure titanium at the bottom. Viable or killed cells of Streptococcus mutans were packed into the well, and $\mathrm{pH}$ at the bacteria-titanium interface was monitored with and without glucose. The corrosion current and passive current was low and stable under killed cells while it increased under viable cells. The polarization resistance and oxygen concentration under killed cells were high and stable, while those under viable cells decreased [48].

\section{Green Inhibitors}

A substance which when added to a corrosive solution in a small concentration causes a reduction in the corrosion rate is known as an inhibitor [47]. Most frequently used corrosion inhibitors include synthetic chemicals such as inorganic and organic compounds. These synthetic chemicals are costly and harmful to the environment [49]. Due to the aforementioned characteristics of chemical corrosion inhibitors, there has been increasing search for eco-friendly corrosion inhibitors. This class of Inhibitors are environmentally friendly and are acquired from natural products [50]. The hunt of such corrosion mitigating agents for metals originated in mid of 1900s [51]. The first eco-friendly green inhibitor (Chelidoniummajus) was applied in the 1930s and it showed better performance than chemical inhibitors [52]. A variety of green organic compounds are known to show excellent properties in shielding metal surfaces against corrosion [53]. Because of the renewable nature, ease of application and availability, biodegradable, and biocompatible nature and being least expensive, several plant extracts have been used earlier [12].

Classification of the eco-friendly green corrosion inhibitor is shown in Fig. 2 [54].

Even though, plant extracts are of biological origin regardless of the aqueous and organic nature, are treated as environmentally benevolent however usually they are accompanied by low protection efficiencies at relatively higher concentration. It is proposed to minimize the growth of microbes on the metal surface which reduces the corrosion rate. One of the greatest challenges of using organic extracts as corrosion inhibitors is their limited solubility's especially at their higher concentration. Another constraint of using plant extracts for mitigating corrosion is that extract preparation is highly tedious as it involves several steps [54].

Moreover, using of organic solvents for extraction may harm the environment. Similarly, application of complex organic molecules, such as ionic liquids and drugs as corrosion alleviating agents is also restricted because its synthesis is extremely expensive. Application of rare earth elements for protection of metals against corrosion is limited by some shortcomings. It is very difficult to separate rare earth element one from another. This discloses the limitation of applied technology. Also, the extraction procedure includes the production of a lot of waste such as ammonia, acids and some radioactive elements, which can possibly disturb the environment if not treated properly. Further the rare earth metals are unstable which may arise as a considerable problem in using those elements as corrosion inhibitors [55]. Few of the extracts have the capacity to hinder microbial growth as they are very efficient reactive oxygen scavengers [56].

Corrosion protection efficiency of organic green corrosion inhibitors (OGCIs) has been connected to the availability of organic compounds including oxygen, nitrogen, Sulphur and phosphorus which have corrosion alleviating potentials for metal attack [57]. OGCIs reveal their protective action via chemisorption or physisorption onto metal/ solution interface by eliminating molecules of water on the metal surface for barrier film formation [58]. The adsorbed

Fig. 2 Broad classification of green inhibitors

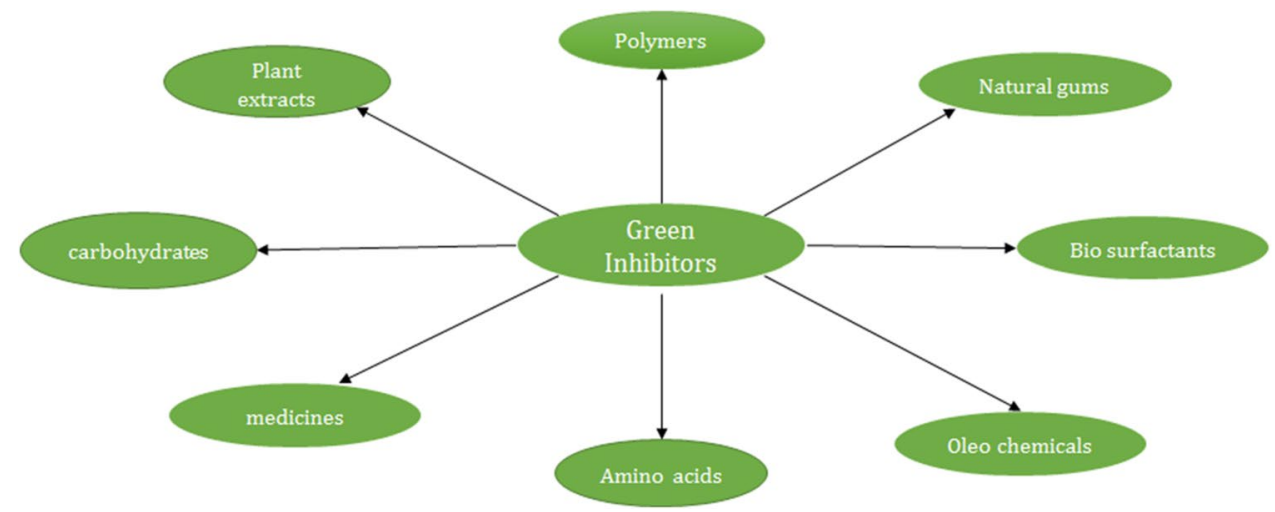


film of inhibitors separates the material from the corrosive environments. Several factors including nature of metal and corrosive environment, temperature, solubility, molecular structure of the inhibitor molecule affects the adsorption behavior of organic corrosion inhibitors [12]. Corrosion alleviation with organic corrosion inhibitors involves two steps: the first consist of the transfer of the corrosion inhibitors over the metal surface and second comprises the interactions between metal and adsorbed inhibitor molecules. Adsorption of the inhibitor molecules on the metal surface is principally governed by its electronic structure and the residual charges present over the surface [59].

A few requirements for selecting the inhibitors are listed in Fig. 3 [60].

The techniques employed to monitor microbial corrosion include open circuit potential (OCP), linear polarization

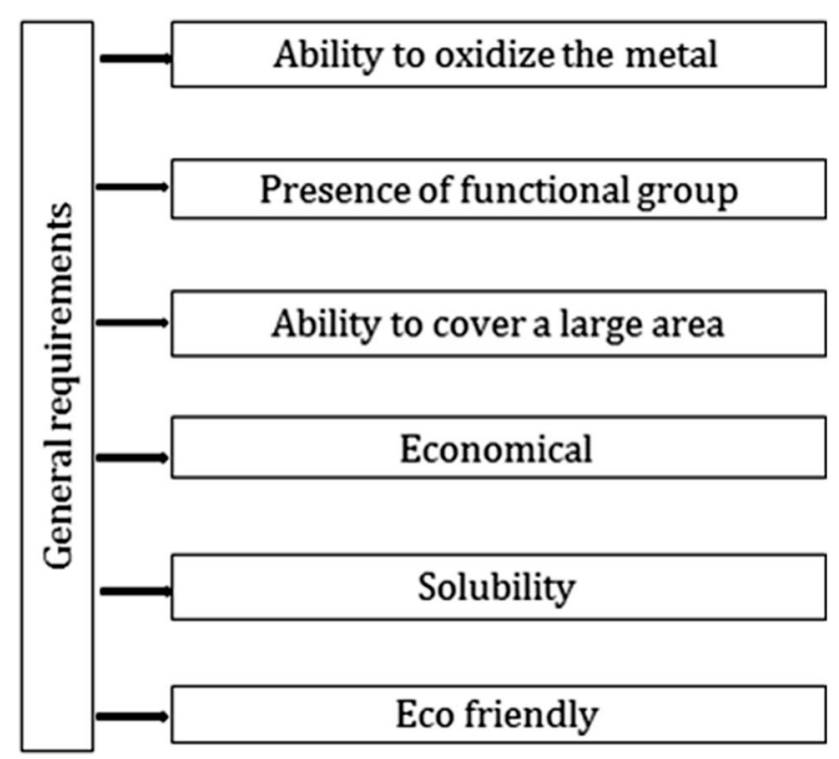

resistance (LPR), electrochemical impedance spectroscopy (EIS) and potentiodynamic polarization curve.

\section{Factors Effecting the Performance of Green Inhibitors}

The efficiency of corrosion inhibitors is dependent on its surface adsorption characteristics. Other factors that influence the protection efficiency include the structure of the inhibitor, its concentration, the test exposure time and most importantly temperature [61].

\section{Factors Affecting MIC}

MIC depends on metal type (host location), nutrients present in the environment and groups of organisms found in the bulk. Microorganisms alter the conditions at the interface between the metal and the substratum, modifying electrochemical reactions, which are fundamental for corrosion processes [62].

\section{Other Applications of Green Inhibitors}

Green inhibitors are used in many industries. The chief applications are listed in Fig. 4 below [63].

Across the world in many countries reinforced concrete is used in construction. Nevertheless the material suffers severe corrosion in certain environments. Corrosion inhibitors are added to the concrete mixing water to increase its corrosion resistance [64]. Nano containers are used to store corrosion inhibitors. Though they are efficient they lack structural features supporting coating dispersion. Therefore corrosion inhibitors are loaded into nanotubes. These find applications in anti-microbial food packaging [65].

Fig. 3 Requirements for selection of inhibitors

Fig. 4 General applications of inhibitors

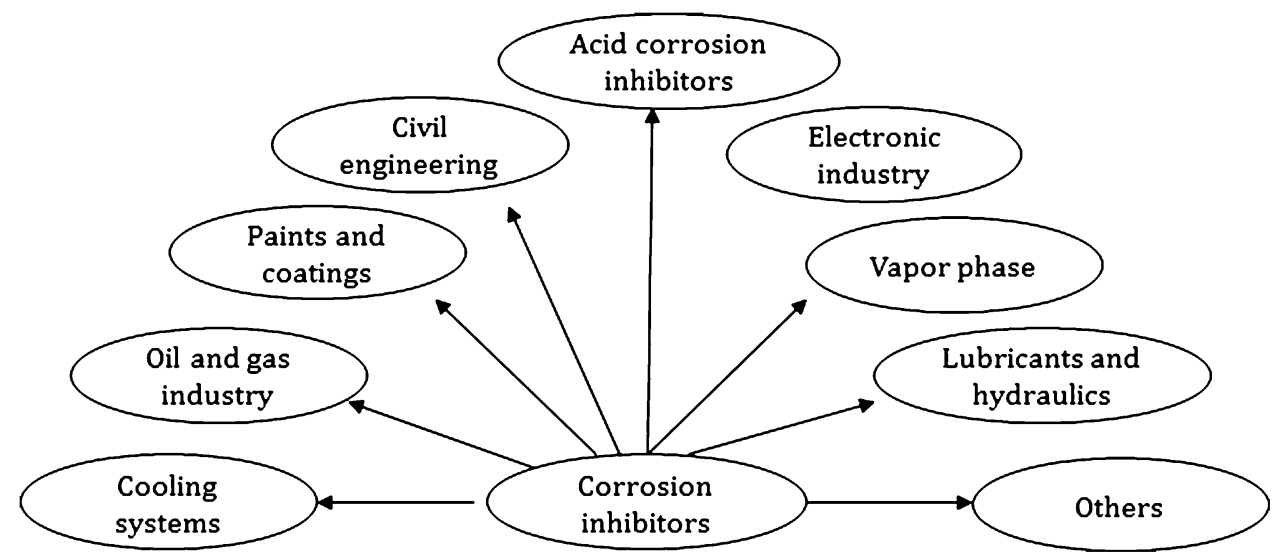


Table 2 Eco-friendly inhibitors applied in various media to mitigate MIC

\begin{tabular}{llll}
\hline Metal & Medium & Inhibitor & References \\
\hline Carbon steel API 5LX & Hypersaline & Neem extract & {$[66]$} \\
Copper & Synthetic sea water & Chitosan polymer & {$[67]$} \\
Aluminum & Phosphoric acid & Cassava starch & {$[68]$} \\
Aluminum & HCl & Exudate gum & {$[69]$} \\
Carbon steel & Phosphoric acid & Etoricoxib (drug) & {$[70]$} \\
Copper and Zinc & Artificial sea water & Tobacco & {$[71]$} \\
X80 steel & HCl & Allium cepa extract & {$[72]$} \\
Carbon steel & Acid and Alkaline medium & Moringa leaf & {$[73]$} \\
304L stainless steel & Medium based on artificial sea water & Cistus ladanifer leaf & {$[74]$} \\
& consisting Pseudomonas aerugi- & & \\
Steel & nosa & & {$[75]$} \\
Mild steel & Winogradsky medium & Aloevera extract & {$[76]$} \\
st37 steel & Cooling water & Ginger extract & {$[77]$} \\
Mild steel & Cooling tower water & Myrtus communis extract & {$[78]$} \\
Mild steel & 1.5\% NaCl & Artemisia pallens & {$[79]$} \\
Mild steel & Crude oil-water environment & Moringa oleifera leaves, \\
Carbon steel & Marine environment & and Carica papaya peels & {$[80]$} \\
\hline & Sulphate reducing bacteria media & Carica papaya & {$[81]$} \\
\hline
\end{tabular}

Few microbial induced corrosion studies carried out with various inhibitors are listed in Table 2.

\section{Summary and Conclusions}

Corrosion inhibitors employed in the industries mostly include synthetic compounds. Although they are effective in mitigating microbial corrosion they are toxic in nature and hazardous to the environment further leading to stringent environmental regulations. Therefore there is a need to develop eco-friendly inhibitors to mitigate microbial corrosion. This publication focuses on various green inhibitors that has been and can be used to inhibit microbial induced corrosion in different metals and media.

Funding Open access funding provided by Manipal Academy of Higher Education, Manipal.

\section{Declarations}

Conflict of interest The authors declare that they have no competing interest.

Open Access This article is licensed under a Creative Commons Attribution 4.0 International License, which permits use, sharing, adaptation, distribution and reproduction in any medium or format, as long as you give appropriate credit to the original author(s) and the source, provide a link to the Creative Commons licence, and indicate if changes were made. The images or other third party material in this article are included in the article's Creative Commons licence, unless indicated otherwise in a credit line to the material. If material is not included in the article's Creative Commons licence and your intended use is not permitted by statutory regulation or exceeds the permitted use, you will need to obtain permission directly from the copyright holder. To view a copy of this licence, visit http://creativecommons.org/licenses/by/4.0/.

\section{References}

1. Patni N, Agarwal S, Shah P (2013) Greener approach towards corrosion inhibition. Chin J Eng 1:10

2. Jawad A, Dhafer S, Zinad D, Dawood Salim R, Al-Amiery A, Sumer Gaaz T, Takriff MS, Kadhum AAH (2019) Synthesis, characterization, and corrosion inhibition potential of novel thiosemicarbazone on mild steel in sulfuric acid environment. Coatings 9:729

3. Ma L, Ren C, Wang J, Liu T, Yang H, Wang Y, Huang Y, Zhang D (2020) Self-reporting coatings for autonomous detection of coating damage and metal corrosion: a review. Chem Eng J 127854

4. Bidi MA, Azadi M, Rassouli M (2020) A new green inhibitor for lowering the corrosion rate of carbon steel in $1 \mathrm{M} \mathrm{HCl} \mathrm{solu-}$ tion: Hyalomma tick extract. Mater Today Commun 24:100996

5. El-Bassi L, Ziadi I, Belgacem S, Bousselmi L, Akrout H (2020) Investigations on biofilm forming bacteria involved in biocorrosion of carbon steel immerged in real wastewaters. Int Biodeterior Biodegrad 150:104960

6. Sachan R, Singh AK (2020) Comparison of microbial influenced corrosion in presence of iron oxidizing bacteria (strains DASEWM1 and DASEWM2). Constr Build Mater 256:119438

7. Swaroop SB, Noyel Victoria S, Manivannan R (2016) Azadirachta indica leaves extract as inhibitor for microbial corrosion of copper by Arthrobacter sulfureus in neutral $\mathrm{pH}$ conditions - a remedy to blue green water problem. Constr Build Mater 64:269-278

8. Rasheed PA, Jabbar KA, Mahmoud KA (2018) Chitosan-based nanocomposite for the inhibition of sulfate reducing bacteria: towards "green" biocides for microbial influenced corrosion in Qatar Foundation Annual Research Conference Proceedings 
9. Hamzah E, Hussain MZ, Ibrahim Z, Abdolahi A (2013) Influence of Pseudomonas aeruginosa bacteria on corrosion resistance of 304 stainless steel. Corros Eng Sci Technol 48(2):116-120

10. Jayaraman N, Mohamad S, AlSalhi AA, Prakash SA, Devanesan S, Rajasekar A, Alfuraydi AA (2019) Impact and role of bacterial communities on biocorrosion of metals used in the processing industry. ACS Omega 4(25):21353-21360

11. $\mathrm{Xu} \mathrm{D}, \mathrm{Gu} \mathrm{T}$ (2014) Carbon source starvation triggered more aggressive corrosion against carbon steel by the Desulfovibrio vulgaris biofilm. Int Biodeterior Biodegrad 91:74-81

12. Alrefaee SH, Rhee KY, Verma C, Quraishi MA, Ebenso EE (2020) Challenges and advantages of using plant extract as inhibitors in modern corrosion inhibition systems: recent advancements. J Mol Liq 321:114666

13. Liu H, Meng G, Li W, Gu T, Liu H (2019) Microbiologically influenced corrosion of carbon steel beneath a deposit in $\mathrm{CO} 2-$ saturated formation water containing Desulfotomaculum nigrificans. Front Microbiol 10:1298

14. Packiavathy IAS, Maruthamuthu S, Gnanaselvan G, Manoharan S, Paul JBJ, Annapoorani A, Kannappan A, Ravi AV (2019) The control of microbially induced corrosion by methyl eugenol-a dietary phytochemical with quorum sensing inhibitory potential. Bioelectrochemistry 128:186-192

15. Zhu Y, Chen L, Xiao H, Shen F, Deng S, Zhang S, He J, Song C, Wang X, Zhang J, Gong L (2020) Effects of disinfection efficiency on microbial communities and corrosion processes in drinking water distribution systems simulated with actual running conditions. J Environ Sci 88:273-282

16. Płaza G, Achal V (2020) Biosurfactants: eco-friendly and innovative biocides against biocorrosion. Int J Mol Sci 21(6):2152

17. Natarajan KA (2018) Biofouling and microbially influenced corrosion. Biotechnology of metals 355-393

18. Jack, Thomas R (2002) Biological corrosion failures

19. Cui YY, Li J, Ding QM (2017) Research of microorganism corrosion properties of 2024-T31 Aluminum-Magnesium alloy in Oil-Water system. Int J Corros 11:2017

20. Wan Y, Zhang D, Liu H, Li Y, Hou B (2010) Influence of sulphate-reducing bacteria on environmental parameters and marine corrosion behavior of Q235 steel in aerobic conditions. Electrochim Acta 55(5):1528-1534

21. Wang W, Li X, Wang J, Xu HWuJ (2004) Influence of biofilms growth on corrosion potential of metals immersed in seawater. Mater Corros 55(1):30-35

22. Zhang T, Wang J, Zhang G, Liu H (2020) The corrosion promoting mechanism of Aspergillus niger on 5083 aluminum alloy and inhibition performance of miconazole nitrate. Corros Sci 176:108930

23. Kumar SR, Krishnaa SD, Krishna MD, Gokulkumar NT, Akilesh AR (2020) Investigation on corrosion behaviour of aluminium 6061-T6 alloy in acidic, alkaline and salt medium. Mater Today 45:1878-1881

24. Wang D, Wu M, Ming J, Shi J (2021) Inhibitive effect of sodium molybdate on corrosion behaviour of AA6061 aluminium alloy in simulated concrete pore solutions. Constr Build Mater 270:121463

25. Quebbou Z, Chafi M, Omari LEH (2021) Corrosion resistance of 5005 aluminum alloy by anodizing treatment in a mixture of phosphoric and boric acids. Mater Today 37:3854-3859

26. Wang J, Xiong F, Liu H, Zhang T, Li Y, Li C, Xia W, Wang H, Liu H (2019) Study of the corrosion behavior of Aspergillus niger on 7075-T6 aluminum alloy in a high salinity environment. Bioelectrochemistry 129:10-17

27. Rajasekar A, Ting YP (2010) Microbial corrosion of aluminum 2024 aeronautical alloy by hydrocarbon degrading bacteria Bacillus cereus ACE4 and Serratia marcescens ACE2. Ind Eng Chem Res 49(13):6054-6061
28. Giacobone AF, Rodriguez SA, Burkart AL, Pizarro RA (2011) Microbiological induced corrosion of AA 6061 nuclear alloy in highly diluted media by Bacillus cereus RE 10 . Int Biodeterior Biodegrad 65(8):1161-1168

29. Hu C, Li T, Yin H, Hu L, Tang J, Ren K (2021) Preparation and corrosion protection of three different acids doped polyaniline/ epoxy resin composite coatings on carbon steel. Colloid Surf A 612:126069

30. Elabbasy HM, Gadow HS (2021) Study the effect of expired tenoxicam on the inhibition of carbon steel corrosion in a solution of hydrochloric acid. J Mol Liq 321:114918

31. Stipaničev M, Turcu F, Esnault L, Schweitzer EW, Kilian R, Basseguy R (2013) Corrosion behavior of carbon steel in presence of sulfate-reducing bacteria in seawater environment. Electrochim Acta 113:390-406

32. Wu T, Xu J, Yan M, Sun C, Yu C, KeW, (2014) Synergistic effect of sulfate-reducing bacteria and elastic stress on corrosion of X80 steel in soil solution. Corros Sci 83:38-47

33. Wang D, Unsal T, Kumseranee S, Punpruk S, Mohamed ME, Saleh MA, Gu T (2021) Sulfate reducing bacterium Desulfovibrio vulgaris caused severe microbiologically influenced corrosion of zinc and galvanized steel. Int Biodeterior Biodegrad 157:105160

34. Lebrini M, Suedile F, Salvin P, Roos C, Zarrouk A, Jama C, Bentiss $F$ (2020) Bagassa guianensis ethanol extract used as sustainable eco-friendly inhibitor for zinc corrosion in 3\% $\mathrm{NaCl}$ : electrochemical and XPS studies. Surf Interfaces 20:100588

35. Juzeliūnas E, Ramanauskas R, Lugauskas A, Leinartas K, Samulevičienė M, Sudavičius A, Juškėnas R (2007) Microbially influenced corrosion of zinc and aluminium-two-year subjection to influence of Aspergillus niger. Corros Sci 49(11):4098-4112

36. Wu Y, Zhang Y, Jiang Y, Qian Y, Guo X, Wang L, Zhang J (2020) Orange peel extracts as biodegradable corrosion inhibitor for magnesium alloy in $\mathrm{NaCl}$ solution: experimental and theoretical studies. J Taiwan Inst Chem Eng 115:35-46

37. Xue D, Yun Y, Tan Z, Dong Z, Schulz MJ (2012) In vivo and in vitro degradation behavior of magnesium alloys as biomaterials. J Mater Sci Technol 28(3):261-267

38. Zhu X, Liu Y, Wang Q, Liu J (2014) Influence of sulfate-reducing bacteria on the corrosion residual strength of an AZ91D magnesium alloy. Materials 7(10):7118-7129

39. Wang Q, Liu YH, Song YL, Zhang DW, Yu SR (2009) Microbiologically influenced corrosion of magnesium alloy based on solid culture medium. J. Jilin Univ, Changchun

40. Maluckov BS (2012) Corrosion of steels induced by microorganisms. Metall Mater Eng 18(3):223-232

41. Hamadi L, Kareche A, Mansouri S, Benbouta S (2020) Corrosion inhibition of $\mathrm{Fe}-19 \mathrm{Cr}$ stainless steel by glutamic acid in $1 \mathrm{M} \mathrm{HCl}$. Chem Data Collect 28:100455

42. Romanovski V, Frantskevich V, Kazlouski V, Kasach A, Paspelau A, Hedberg Y, Romanovskaia E (2020) Inappropriate cleaning treatments of stainless steel AISI 316L caused a corrosion failure of a liquid transporter truck. Eng Fail Anal 117:104938

43. Landoulsi J, Kirat KE, Richard C, Feron D, Pulvin S (2008) Enzymatic approach in microbial-influenced corrosion: a review based on stainless steels in natural waters. Environ Sci Technol 42(7):2233-2242

44. Khouzani K, Bahrami M, Hosseini-Abari A, Khandouzi M, Taheri $P$ (2019) Microbiologically influenced corrosion of a pipeline in a petrochemical plant. Metals 9(4):459

45. Khan MS, Li Z, Yang K, Xu D, Yang C, Liu D, Lekbach Y, Zhou E, Kalnaowakul P (2019) Microbiologically influenced corrosion of titanium caused by aerobic marine bacterium Pseudomonas aeruginosa. J Mater Sci Technol 35(1):216-222

46. Fukushima A, Mayanagi G, Nakajo K, Sasaki K, Takahashi N (2014) Microbiologically induced corrosive properties of the titanium surface. J Dent Res 93(5):525-529 
47. Chaubey N, Qurashi A, Chauhan DS, Quraishi MA (2020) Frontiers and advances in green and sustainable inhibitors for corrosion applications: a critical review. J Mol Liq 114385

48. Hamadi L, Mansouri S, Oulmi K, Kareche A (2018) The use of amino acids as corrosion inhibitors for metals: a review. Egypt $\mathbf{J}$ Pet 27(4):1157-1165

49. Znini M, Majidi L, Bouyanzer A, Paolini J, Desjobert JM, Costa J, Hammouti B (2012) Essential oil of Salvia aucheri mesatlantica as a green inhibitor for the corrosion of steel in $0.5 \mathrm{M} \mathrm{H} 2 \mathrm{SO} 4$. Arab J Chem 5(4):467-474

50. Heidarshenas B, Zhou L, Hussain G, Li Q, Ostrikov KK (2020) Green inhibitors for steel corrosion in acidic environment: stateof-art. Mater Today Sustain 10:100044

51. Kokilaramani S, Al-Ansari MM, Rajasekar A, Al-Khattaf FS, Hussain A, Govarthanan M (2020) Microbial influenced corrosion of processing industry by re-circulating waste water and its control measures-a review. Chemosphere 129075

52. Miralrio A, Espinoza Vázquez A (2020) Plant extracts as green corrosion inhibitors for different metal surfaces and corrosive media: a review. Processes 8(8):942

53. Verma C, Ebenso EE, Bahadur I, Quraishi MA (2018) An overview on plant extracts as environmental sustainable and green corrosion inhibitors for metals and alloys in aggressive corrosive media. J Mol Liq 266:577-590

54. El Ibrahimi B, Jmiai A, Bazzi L, El Issami S (2020) Amino acids and their derivatives as corrosion inhibitors for metals and alloys. Arab J Chem 13(1):740-771

55. Gece G (2011) Drugs: a review of promising novel corrosion inhibitors. Corros Sci 53(12):3873-3898

56. Popoola LT (2019) Progress on pharmaceutical drugs, plant extracts and ionic liquids as corrosion inhibitors. Heliyon 5(2): $\mathrm{e} 01143$

57. Finšgar M, Jackson J (2014) Application of corrosion inhibitors for steels in acidic media for the oil and gas industry: a review. Corros Sci 86:17-41

58. Verma C, Haque J, Quraishi MA, Ebenso EE (2019) Aqueous phase environmental friendly organic corrosion inhibitors derived from one step multicomponent reactions: a review. J Mol Liq 275:18-40

59. Aljourani J, Raeissi K, Golozar MA (2009) Benzimidazole and its derivatives as corrosion inhibitors for mild steel in $1 \mathrm{M} \mathrm{HCl}$ solution. Corros Sci 51(8):1836-1843

60. Popoola LT (2019) Organic green corrosion inhibitors (OGCIs): a critical review. Corros Rev 37(2):71-102

61. Wikieł AJ, Datsenko I, Vera M, Sand W (2014) Impact of Desulfovibrio alaskensis biofilms on corrosion behaviour of carbon steel in marine environment. Bioelectrochemistry 97:52-60

62. Shehata OS, Korshed LA, Attia A (2017) Green corrosion inhibitors, past, present, and future. Corrosion inhibitors, principles and recent applications 121

63. Parthipan P, Narenkumar J, Elumalai P, Preethi PS, Nanthini AUR, Agrawal A, Rajasekar A (2017) Neem extract as a green inhibitor for microbiologically influenced corrosion of carbon steel API 5LX in a hypersaline environments. J Mol Liq 240:121-127

64. Al-Akhras N, Mashaqbeh Y (2021) Potential use of eucalyptus leaves as green corrosion inhibitor of steel reinforcement. J Build Eng 35:101848

65. Kumar SS, Kakooei S, Ismail MC, Haris M (2020) Synthesis and characterization of metal ion end capped nanocontainer loaded with duo green corrosion inhibitors. J Mater Res Technol 9(4):8350-8354

66. El Mouaden K, El Ibrahimi B, Oukhrib R, Bazzi L, Hammouti B, Jbara O, Tara A, Chauhan DS, Quraishi MA (2018) Chitosan polymer as a green corrosion inhibitor for copper in sulfide-containing synthetic seawater. Int J Biol Macromol 119:1311-1323
67. Deng S, Li X, Du G (2020) An efficient corrosion inhibitor of cassava starch graft copolymer for aluminium in phosphoric acid. Chin J Chem Eng

68. Umoren SA, Obot IB, Ebenso EE, Obi-Egbedi NO (2009) The inhibition of aluminium corrosion in hydrochloric acid solution by exudate gum from Raphia hookeri. Desalination 247(1-3):561-572

69. Anaee RA, Tomi IHR, Abdulmajeed MH, Naser SA, Kathem MM (2019) Expired Etoricoxib as a corrosion inhibitor for steel in acidic solution. J Mol Liq 279:594-602

70. Singh A, Dayu X, Ituen E, Ansari K, Quraishi MA, Kaya S, Lin Y (2020) Tobacco extracted from the discarded cigarettes as an inhibitor of copper and zinc corrosion in an ASTM standard D1141-98 (2013) artificial seawater solution. J Mater Res Technol 9(3):5161-5173

71. Ituen E, Singh A, Yuanhua L (2020) Inhibitive effect of onion mesocarp extract-nickel nanoparticles composite on simultaneous hydrogen production and pipework corrosion in $1 \mathrm{M} \mathrm{HCl}$. Int $\mathrm{J}$ Hydrogen Energy 45(18):10814-10825

72. Anadebe VC, Okafor CS, Onukwuli OD (2020) Electrochemical, molecular dynamics, adsorption studies and anti-corrosion activities of Moringa leaf biomolecules on carbon steel surface in alkaline and acid environment. Chem Data Collect 28:100437

73. Yassir L, Dake Xu, El Abed S, Dong Y, Dan Liu M, Khan S, Koraichi SI, Yang Ke (2018) Mitigation of microbiologically influenced corrosion of 304L stainless steel in the presence of Pseudomonas aeruginosa by Cistus ladanifer leaves extract. Int Biodeter Biodegr 133:159-169

74. Agwa OK, Iyalla D, Abu GO (2017) Inhibition of bio corrosion of steel coupon by sulphate reducing bacteria and Iron oxidizing bacteria using Aloe Vera (Aloe barbadensis) extracts. JASEM 21(5):833-838

75. Narenkumar J, Parthipan P, Nanthini AUR, Benelli G, Murugan K, Rajasekar A (2017) Ginger extract as green biocide to control microbial corrosion of mild steel. 3 Biotech 7(2):1-11

76. Zadeh FMH, Khaleghi M, Bordbar S, Jafari A (2020) Myrtus communis extract: a bio-controller for microbial corrosion induced by sulphate reducing bacteria. Corros Eng Sci Technol $1-10$

77. Kokilaramani S, AlSalhi MS, Devanesan S, Narenkumar J, Rajasekar A, Govarthanan M (2020) Bacillus megateriuminduced biocorrosion on mild steel and the effect of Artemisia pallens methanolic extract as a natural corrosion inhibitor. Arch Microbiol 202(8):2311-2321

78. Agarry SE, Oghenejoboh KM, Aworanti OA, Arinkoola AO (2019) Biocorrosion inhibition of mild steel in crude oil-water environment using extracts of Musa paradisiaca peels, Moringa oleifera leaves, and Carica papaya peels as biocidal-green inhibitors: kinetics and adsorption studies. Chem Eng Commun 206:98-124

79. Nwigwe US, Mbam SO, Umunakwe R (2019) Evaluation of Carica papaya leaf extract as a bio-corrosion inhibitor for mild steel applications in a marine environment. Mater Res Express 6(10): 105107

80. Rasheed PA, Pandey RP, Jabbar KA, Samara A, Abdullah AM, Mahmoud KA (2020) Chitosan/lignosulfonate nanospheres as "green" biocide for controlling the microbiologically influenced corrosion of carbon steel. Materials 13(11):2484

81. AlAbbas FM, Bhola SM, Spear JR, Olson DL, Mishra B (2013) The shielding effect of wild type iron reducing bacterial flora on the corrosion of line pipe steel. Eng Fail Anal 33:222-235

Publisher's Note Springer Nature remains neutral with regard to jurisdictional claims in published maps and institutional affiliations. 